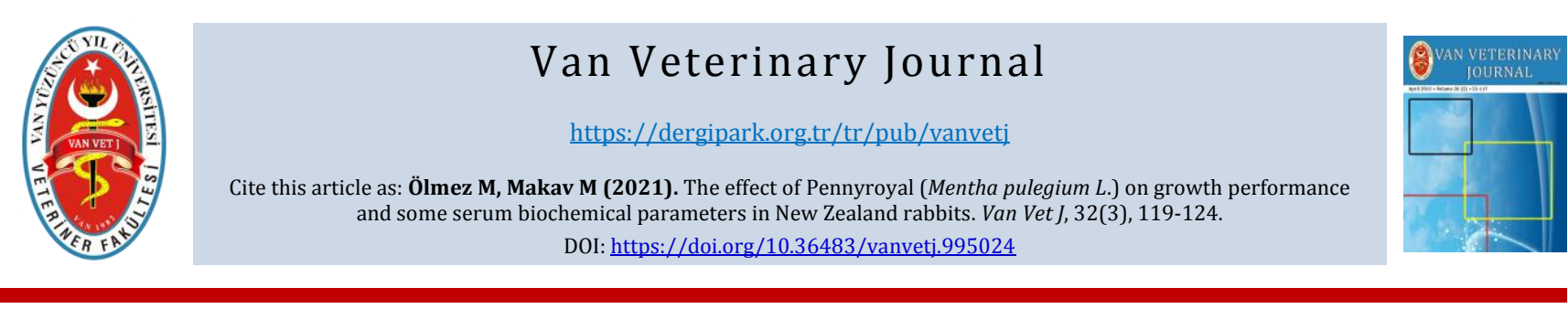

ISSN: 2149-3359

Original Article

e-ISSN: 2149-8644

\title{
The Effect of Pennyroyal (Mentha Pulegium L.) on Growth Performance and Some Serum Biochemical Parameters in New Zealand Rabbits
}

\author{
Mükremin ÖLMEZ1,*(D) Mustafa MAKAV2 (0) \\ ${ }^{1}$ Department of Animal Nutrition and Nutritional Diseases, Kafkas University, 36100, Kars, Turkey \\ 2 Department of Physiology, Faculty of Veterinary Medicine, Kafkas University, 36100, Kars, Turkey
}

Received: 14.09 .2021

Accepted: 01.11.2021

\begin{abstract}
This study was to identify the effects of dried aerial parts powder pennyroyal added to rabbit diets on growth performance and some serum biochemical parameters. The research utilized 15 New Zealand rabbits weighing 2-2.1 kg on average. It employed control and two experimental groups with five rabbits each. All rabbits were hosted in individual cages. While basal diet was provided to the control group, pennyroyal (Mentha pulegium L.) powder was given at $0.1 \%(\mathrm{P} 1$ ) and $0.2 \%(\mathrm{P} 2$ ) levels to the treatment groups, respectively. The trial lasted for 28 days. It was measured body weight and feed consumption of animals at the beginning and end of the experiment. Blood samples were taken from rabbits on days 0,14 and 28 of the study and the changes of serum biochemical parameters throughout the study were analyzed. There were no differences between the groups in terms of performance parameters $(\mathrm{P}>0.05)$. It was observed that the high point result was that the pennyroyal lowered the serum cholesterol level $(\mathrm{P}<0.05)$. However, pennyroyal did not affect other biochemical parameters $(\mathrm{P}>0.05)$. In conclusion, it was noted that pennyroyal might be used as an alternative growth promoter and cholesterol regulator to rabbit diets. In particular, up to $0.2 \%$ pennyroyal may utilize in rabbit diets.
\end{abstract}

Keywords: Biochemical parameters, Cholesterol, Mentha pulegium, Performance, Rabbit.

öz

\section{Yarpuzun (Mentha pulegium L.) Yeni Zelanda tavşanlarında büyüme performansı ve bazı serum biyokimyasal parametreleri üzerine etkisi}

Bu çalışma, tavşan diyetlerine ilave edilen yarpuzun (Mentha pulegium L.) kurutulmuş yeşil kısımlarının büyüme performansı ve bazı serum biyokimyasal parametreleri üzerindeki etkilerini belirlemek amacıyla yapılmıștır. Araștırmada ortalama 2-2.1 kg ağırlığında 15 Yeni Zelanda tavşanı kullanıldı. Her birinde beș tavşan bulunan kontrol ve iki deneme grubu dizayn edildi. Tüm tavşanlar bireysel kafeslerde barındırıldı. Kontrol grubuna bazal diyet verilirken, deneme gruplarına sırasıyla \%0.1 (P1) ve \%0.2 (P2) seviyelerinde yarpuz tozu verildi. Deneme 28 günde tamamlandı. Canlı ağırlık ve yem tüketimleri deneme başı ve sonunda yapılan tartımlarla belirlendi. Çalışmanın 0, 14 ve 28. günlerinde tavşanlardan kan örnekleri alınarak serum biyokimyasal parametrelerinin çalıșma boyunca değișimi analiz edildi. Performans parametreleri açısından gruplar arasında fark bulunmadı $(\mathrm{P}>0.05)$. Yarpuzun serum kolesterol seviyesini düşürdügü belirlendi $(\mathrm{P}<0.05)$. Ancak yarpuzun diğer biyokimyasal parametreler üzerine etkisinin olmadığı belirlendi $(\mathrm{P}>0.05)$. Sonuç olarak, yarpuzun tavşan diyetlerine alternatif bir büyüme destekleyici ve kolesterol düzenleyici olarak kullanılabileceği belirlendi. Özellikle tavşan diyetlerinde \%0.2'ye kadar yarpuz kullanılabileceği kanaati oluşmuştur.

Anahtar Kelimeler: Biyokimyasal parametreler, Kolesterol, Mentha pulegium, Performans, Tavşan.

\section{INTRODUCTION}

Disease due to the deterioration of microflora in rabbits' digestive system can pave the way for problems that can result in death (Bäuerl et al. 2014). Antibiotics have been used for many years as feed additives to prevent such ailments (Cesari et al. 2008). Following the European Union's prohibition of antibiotics as feed additives, the pursuit for alternative feed additives have increased, and many products such as antibiotics have been employed in trials (Wahyuni et al. 2019). Researchers support those aromatic plants can be a natural alternative among growth 
promoters for animal production (Losa and Kohler 2001; Şahin et al. 2012; Ölmez et al. 2020). Such plants secrete various secondary metabolites (volatile network, flavonoid, alkaloid, saponin) during their development (Şahin et al. 2020). Many biological and pharmaceutical effects of such metabolites have been identified, including antioxidant, antimicrobial and anti-inflammatory actions (Zengin et al. 2018). Besides, we observe that they demonstrate effects that protect the physiological health of living things with their appetite-enhancing, digestive system-regulating, and beneficial microorganismssupporting properties (El-kaiaty et al. 2020).

Labiatae (Lamiaceae) family, one of the nearly 300 plant families that grow in nature, is known to be one of the most widely used aromatic plants for many purposes in the World (Ishtiaq et al. 2014). Mentha, a member of the Labiatae family, is widely used in medicine, food, and cosmetics while spreading from the Mediterranean to Central Asia (Elshafie and Camele 2017). Pennyroyal (Mentha pulegium L.), one of the twenty species of Mentha herbs is a perennial aromatic herbaceous plant that can grow than half a meter (Gruenwald et al. 2000). The dried parts and the essential oil obtained from them are widely used in traditional medicine (respiratory system ailments, digestion, liver and gallbladder disorders), gastronomy (spices, snacks), aromatherapy, and cosmetics (Ahmed et al. 2018). It has also been known that pennyroyal has many physiological, biochemical, and pharmacological effects, thanks to its phenolics. Linalool and Menthone have been identified to be the main constituent of Pennyroyal (Velpandian et al. 2001). In previous research, it has been reported that pennyroyal protects the welfare of animals and increases their growth performance by showing growth-promoting, regulating intestinal flora and antioxidant action (Abedini et al. 2017; Reyan Mohasesi et al. 2020; Makav and Ölmez 2021; Ölmez et al. 2021).

This study aimed to identify the pennyroyal's effect on performance and some serum biochemical parameters in rabbits.

\section{MATERIAL AND METHODS}

\section{Ethics committee permission}

This research was conducted with the permission of the Kafkas University Animal Experiments Local Ethics Committee (KAÜ-HADYEK/2020-123).

\section{Animals and Trial Design}

A total of fifteen New Zealand rabbits of age with an initial body weight of 2-2.1 kg were utilized in the experiment. The rabbits were obtained from the Atatürk University Experimental Animal Breeding Unit, which is officially authorized to breed and sell experimental animals. Rabbits were housed individually in species-specific cages and fed ad libitum. The environment in which the cages were located was kept at a comfortable temperature $\left(24^{\circ} \mathrm{C}\right)$. The environment was illuminated with a 12-hour light-12hour dark system. The rabbits were fed with a diet prepared per their needs in Table 1 (Halls 2010). The rabbits were divided into three experimental groups (Control, $0.1 \%$ pennyroyal (P1) and $0.2 \%$ pennyroyal (P2)), with five rabbits in the group. While the rabbits in the control group were provided with the basal diet, pennyroyal powder to the groups' feed was added at a level of $0.1 \%(\mathrm{P} 1)$ and $0.2 \%(\mathrm{P} 2)$, respectively. The trial was completed in 28 days.
Table 1. Nutrient content and chemical analysis of the diet.

\begin{tabular}{ll}
\hline Ingredients & $\%$ \\
\hline Barley & 14.00 \\
Wheat & 21.00 \\
Maize & 16.00 \\
Wheat bran & 15.00 \\
Oak husk & 4.00 \\
Soybean meal & 8.00 \\
Cotton seed meal & 10.00 \\
Clover flour & 5.00 \\
Vegetable oil & 2.00 \\
Molasses & 1.00 \\
Dicalcium phosphate & 1.80 \\
Marble dust & 1.60 \\
Salt & 0.35 \\
Vit-min mix & 0.25 \\
\hline Analysis & \\
\hline Dry matter, \% & 89.79 \\
Crude protein, \% & 15.83 \\
Metabolizable energy (Kcal/kg) & 2500.00 \\
Crude fibre, \% & 8.98 \\
Crude fat, \% & 4.48 \\
Ash, \% & 7.83 \\
\hline Pention &
\end{tabular}

\section{Pennyroyal (Mentha pulegium L.)}

The pennyroyal was collected during the season from Boğatepe village $\left(40^{\circ} 48^{\prime} 21.2^{\prime N}{ }^{\circ} 2^{\circ} 53^{\prime} 37.8^{\prime \prime}\right.$ E) of Kars province. The plant was dried and powdered without solarizing at room temperature. The essential oil was obtained via the water vapor distillation method and performed GC/MS analysis. The analysis reveals that the pennyroyal's major compounds were Linalool (13.61\%) and Menthone $(10.56 \%)$. The powder of pennyroyal was used in the trial.

\section{Performance Parameters}

All rabbits were individually weighed every week during the trial, and body weight (BW) and body weight gains (BWG) were calculated and recorded. Also, feed consumption (FC) was identified by removing the remaining feed. The feed conversion ratio (FCR) was identified by dividing the resulting feed consumption by increasing body weight.

\section{Sampling and analysis}

Blood samples were taken from rabbits' ear veins on the 0 th, $14^{\text {th }}$, and $28^{\text {th }}$ days. Blood samples were centrifuged at $3000 \mathrm{rpm}$ for 5 minutes. All samples were stored at $-20^{\circ} \mathrm{C}$ until the analysis day. Glucose, cholesterol, triglyceride, total protein, urea, calcium, and phosphorus levels in serum samples thawed at $+4{ }^{\circ} \mathrm{C}$ on the day of analysis identified by the kit procedure by using Enzyme-Linked ImmunoSorbent Assay (ELISA-Elabscience ${ }^{\circledR} \quad$ UK) commercial kits.

\section{Statistical Analysis}

The data were analyzed using the One-Way ANOVA in statistical software GraphPad Prism 8 (San Diego, CA). The post-hoc test (Tukey) measured differences of means. Statistical significances were adopted to be $\mathrm{P}<0.05$. 


\section{RESULTS}

Table 2 illustrated the effect of pennyroyal supplementation to rabbit diet on performance values such as BW, BWG, FC, and FCR. No differences were among the groups in the initial and final BW's $(P>0.05)$. The effect of pennyroyal on BWG was limited $(\mathrm{P}>0.05)$. Considering the $\mathrm{FC}$, there were no differences among all groups (P> 0.05). When the FCR's were calculated, no significant differences were discerned among the results $(\mathrm{P}>0.05)$.

Table 2. The effect of Pennyroyal on performance parameters.

\begin{tabular}{lcccc}
\hline Parameters & Control & P1 & P2 & $\mathrm{p}$ \\
\hline Initial BW (g) & 2049.33 & 2051.67 & 2054.42 & $\mathrm{P}>0.05$ \\
& \pm 30.02 & \pm 15.41 & \pm 8.97 & \\
Final BW (g) & 2201.00 & 2205.67 & 2212.75 & $\mathrm{P}>0.05$ \\
& \pm 31.24 & \pm 13.54 & \pm 9.82 & \\
BWG (g/day) & 5.42 & 5.50 & 5.65 & $\mathrm{P}>0.05$ \\
& \pm 0.09 & \pm 0.11 & \pm 0.15 & \\
FC (g/day) & 23.02 & 23.49 & 24.37 & $\mathrm{P}>0.05$ \\
& \pm 0.61 & \pm 0.41 & \pm 0.73 & \\
FCR (g/g) & 4.25 & 4.27 & 4.31 & $\mathrm{P}>0.05$ \\
& \pm 0.05 & \pm 0.04 & \pm 0.05 & \\
\hline
\end{tabular}

P1: 0.1\% Pennyroyal, P2: 0.2\% Pennyroyal, BW: Body weight, BWG: Body weight gain, FC: Feed consumption, FCR: Feed conversion ratio.

The results reveal that the pennyroyal's effect on glucose, total protein, urea and triglyceride levels were not significant $(\mathrm{P}>0.05)$. Cholesterol level was significantly decreased in all the pennyroyal groups on the 14th and 28th days of study $(\mathrm{P}<0.05)$. The lowest cholesterol level was determined in P2 group last (28th) day of the study. The pennyroyal did not influence serum calcium and phosphorus level $(\mathrm{P}>0.05)$ (Figure 1).

\section{DISCUSSION AND CONCLUSION}

This study was carried to evaluate pennyroyal's impact on performance and some blood biochemical parameters in rabbits. No change was found in the groups to which $0.1 \%$ and $0.2 \%$ pennyroyal was added compared to the control group. Findings reveal that the effect of adding pennyroyal powder to rabbit diets on growth performance was limited. Similar performance results have been reported in studies with Labiatae plants (Abd El-Hady et al. 2013; Zeweil et al. 2017). Benlemlih et al. (2020) reported that the supplementation of thyme and oregano to diets of growing rabbits had no effect on performance parameters. Also, these results were consistent with the literature research of Alagawany et al. (2016) that 2, 4, $6 \mathrm{~g} / \mathrm{kg}$ turmeric addition and of Peiretti et al. (2011) that $3 \mathrm{~g} / \mathrm{kg}$ turmeric supplementation to rabbit diets did not affect the growth performance. Similarly, Basavaraj et al. (2011) stated that dietary turmeric did not change BWG and FC in rabbits. Consistent with the current study, it was identified that adding 100 and $200 \mathrm{mg} / \mathrm{kg}$ oregano extract and $0.15 \%$ rosemary oil to rabbit diets did not affect performance (Botsoglou et al. 2004; Erdelyi et al. 2008).

Some studies differed from the results of the present study (Rotolo et al. 2013; Cardinali et al. 2015). Pebriansyah et al. (2019) observed that the addition of phytogenic feed additives significantly affects BWG and FC parameters. Similarly, the addition of thyme oil to rabbit diets has been reported to improve body weight gain (Placha et al. 2013).
We note that aromatic herbs affect feed intake and digestion of nutrients and increase performance by regulating the digestive system (Adibmoradi et al. 2006). It was observed in another study that the addition of thyme to the diet of New Zealand rabbits positively affected growth performance, especially in the group with 5\% thyme extract, body weight was higher than in the control group (Ibrahim et al. 2000; Alagawany et al. 2016). In another study, it was reported that the supplementation of thyme oil reduced body weight gain but did not show any effect on feed consumption (El-Azeem et al. 2019). Differences of the results are considered to be caused by changes related to the kind, derivatives, harvest time, from of the aromatic plants. It could not be found any literature on the supplementation of pennyroyal to rabbit diets. Therefore, it has been discussed in studies with plants in the same family and genus. We believe that it will shed light on future studies within this scope.

Pennyroyal powder added to rabbit diets at different levels had no overall effect on blood parameters. Serum glucose level was not affected by pennyroyal's addition during the whole trial $(\mathrm{P}>0.05)$. In a similar study, El-kaiaty et al. (2020) reported that the addition of thyme oil to rabbit diets did not affect the serum glucose level. These results were consistent with the results of El-Gogary et al. (2018) that adding rosemary to rabbit diets and of Al-Jamal and Alqadi (2011) that adding rosemary to rat diets did not alter serum glucose levels. Unlike this study, Abd-El-Hady (2014) reported that the herbal supplement to the rabbit diets significantly increased the serum glucose level in the middle of the study compared to the control group. Similarly, Ibrahim et al. (2000) described that the addition of $0.5 \%$ peppermint and thyme to male New Zealand rabbit diets significantly increased serum glucose level. It was identified that aromatic herbs and their products could increase pancreatic activity and affect glucose levels (Moore 2010).

Serum total protein results at the end of the trial are compatible with the results of Abd-El-Hady (2014) that it was not affected by adding 300 and $400 \mathrm{~g} /$ ton of herbal additives to rabbit diets. Tousson et al. (2011) reported that $2 \mathrm{~kg} /$ ton black seed and thyme in the rabbit diets did not change the total protein values compared to the control. In a different study, it was observed that thyme oil significantly decreased total protein value in growing rabbits compared to the control group (El-kaiaty et al. 2020). It is believed that the added aromatic herbs' differences in glucose and protein results may be affected depending on the feed consumption.

Blood urea results were not affected by pennyroyal's supplementation $(\mathrm{P}>0.05)$. Contrary to the present trial, studies reported that the addition of thyme and oregano oil significantly reduced urea, one of the kidney function parameters, as a positive indicator compared to the control group (Tousson et al. 2011; El-kaiaty et al. 2020).

Serum cholesterol level decreased significantly in the groups that added $0.1 \%$ and $0.2 \%$ pennyroyal to the rabbit diets compared to the control group. However, the serum triglyceride level did not alter among the groups. Thus, with supplementation of $2 \mathrm{~g} /$ ton thyme to the rabbit diets, the cholesterol level decreased significantly, while the triglyceride level did not change (Tousson et al. 2011). Cholesterol level decreased, while triglyceride level did not change significantly in the study investigating the effect of oregano oil added to drinking water at the level of $1 \mathrm{ml} / \mathrm{L}$ in growing rabbits on performance and blood parameters (El-kaiaty et al. 2020). While El-Gogary et al. (2018) 
reported no significant change in cholesterol and triglyceride levels by giving rosemary oil to rabbit diets, Abd-El-Hady (2014) reported that the phytogenic feed additive decreased cholesterol and triglyceride levels in rabbits during the growing period. The phenolic ingredient of aromatic herbs is known to inhibit cholesterol absorption in the digestive system. It was also attributed that pennyroyal can decrease cholesterol by hindering 3 Hydroxy-3-methylglutaryl coenzyme A (HMG-CoA) reductase, which is the enzyme involved in cholesterol synthesis (Elson and Qureshi 1995).

It has also been reported that polyphenols with high antioxidant activity show cholesterol-lowering activity. Phenolic compounds of pennyroyal have also been observed to have high antioxidant activity (Sunarno et al. 2019; Makav and Ölmez 2021). The pennyroyal acts a crucial role in lowering cholesterol levels, and the difference between some research varies depending on the use, dose, and application of aromatic herbs with different components. The supplementation of pennyroyal did not significantly affect serum calcium and phosphorus levels during the whole trial. No literature data is available to

Glucose

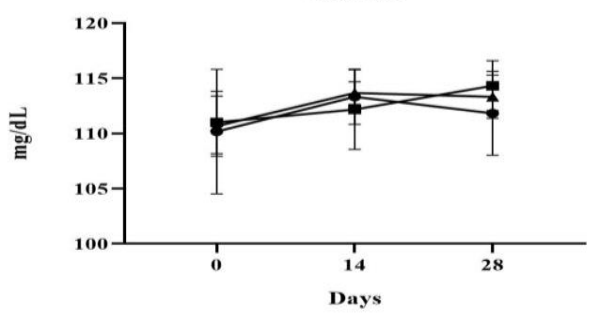

$\rightarrow$ Control
$-\mathrm{P} 1$

$=\mathrm{P} 1$
$\approx \mathrm{P} 2$

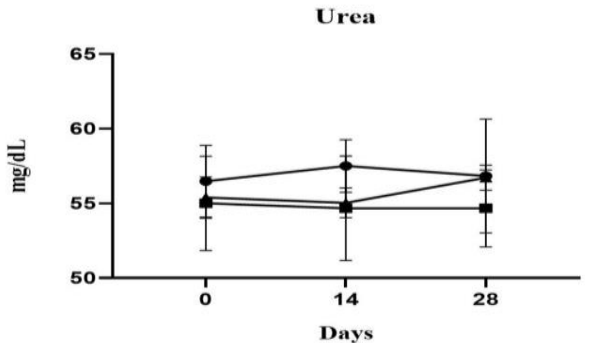

- Contro

$-\mathrm{P} 1$

$\rightarrow \mathrm{P} 2$
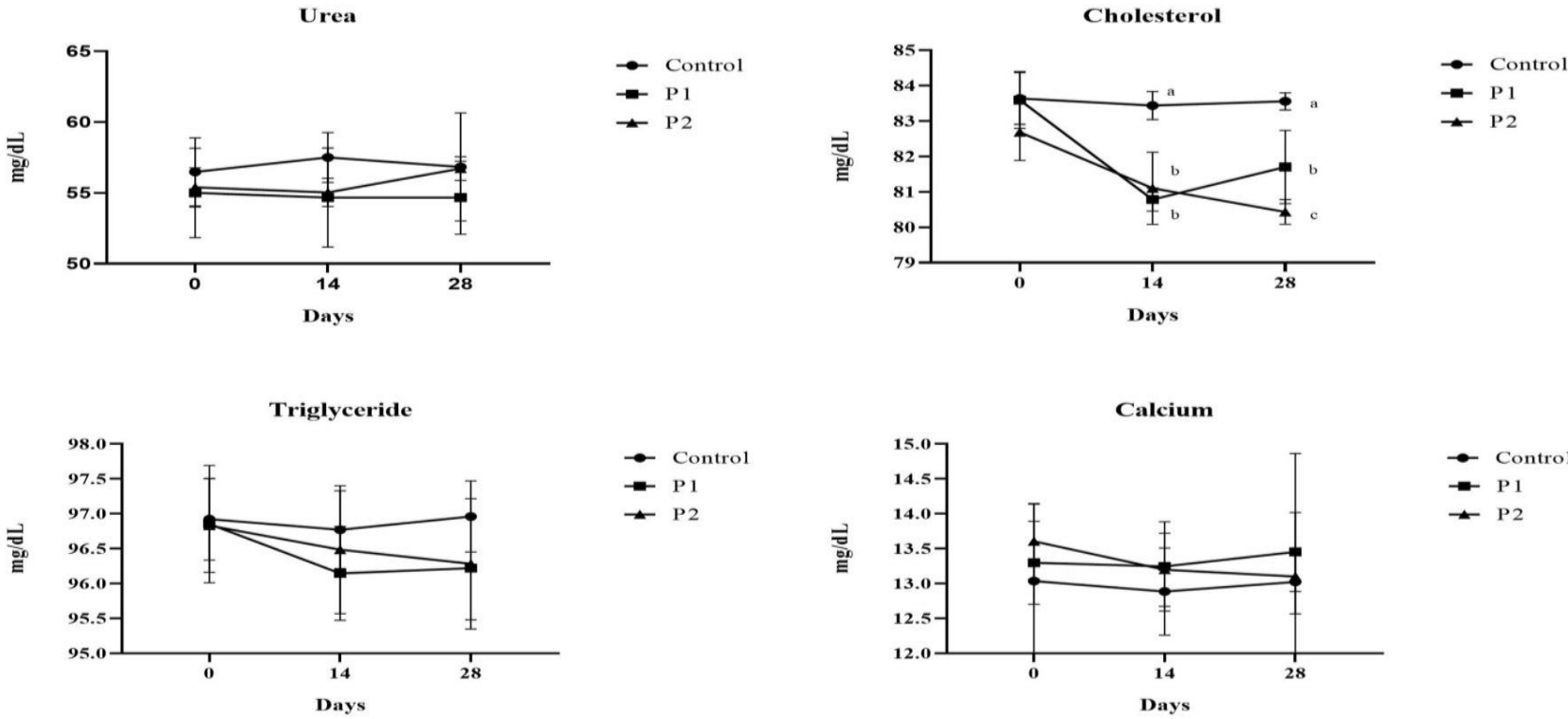

analyze the effects of aromatic herbs and products on serum calcium and phosphorus levels in New Zealand rabbits. The available data are consistent with some research on monogastric animals and analyze aromatic herbs and products (Khaksar et al. 2012; Cengiz et al. 2016). In another study, the essential oil mixture reduced the serum calcium level but did not change the broiler's serum phosphorus level (Chen et al. 2013). However, the effect of aromatic herb mixtures on serum biochemical parameters in laying hens reveals that serum calcium and phosphorus levels increased and that herbal components increased the absorption of these minerals from the intestine into the bloodstream (Sakthi Priya et al. 2017). It is believed that the differences observed are animal species, diet composition, variety, aromatic plants, and feeding conditions.

As a result of the study, cruces of the trial were the decrease in serum cholesterol level with the supplementation of pennyroyal. So, it is believed that the pennyroyal may be safely used as an alternative growth promoter, as it is observed that pennyroyal has some benefits on health of rabbits.
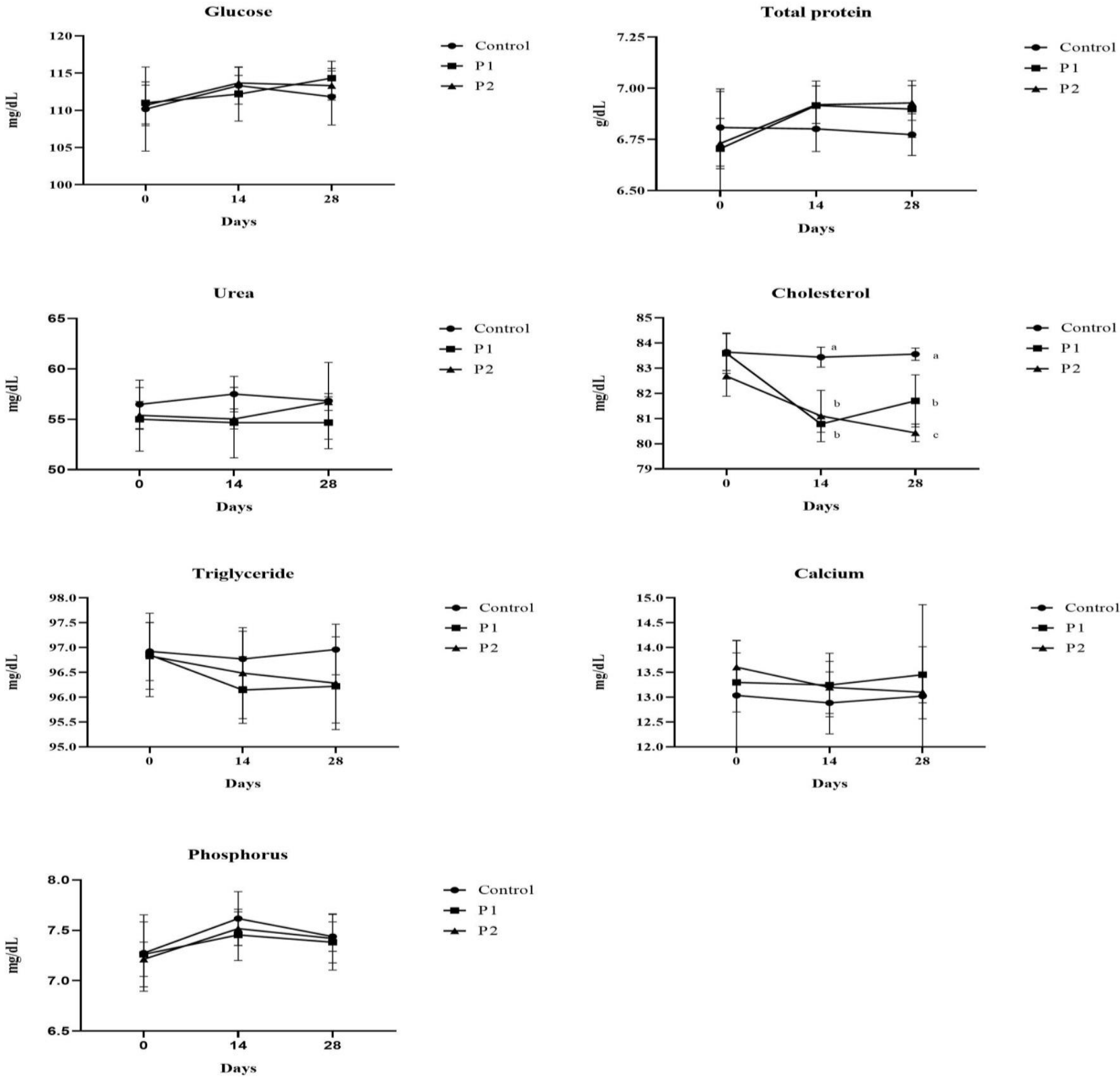

Figure 1. The effect of Pennyroyal on biochemical parameters.

P1: 0.1\% Pennyroyal; P2: 0.2\% Pennyroyal a,b,c: Means in the same column with different superscripts differ $(\mathrm{P}<0.05)$ 


\section{CONFLICTS OF INTEREST}

No potential conflict of interest was reported by the authors.

\section{AUTHOR CONTRIBUTIONS}

Idea / Concept: MÖ

Supervision / Consultancy: MM

Data Collection and / or Processing: MÖ, MM

Analysis and / or Interpretation: MÖ, MM

Writing the Article: MÖ

Critical Review: MM

\section{REFERENCES}

Abd-El-Hady A (2014). Performance, physiological parameters and slaughter characteristics in growing rabbits as affected by a herbal feed additives (DIGESTAROM). J Int Sci Publ Agric Food, 2, 353-365.

Abd El-Hady A, El-Ghalid O, El-Raffa A (2013). Influence of a herbal feed additives (Digestarom $($ ) on productive performance and blood constituents of growing rabbits. Egypt J Anim Prod, 50 (1), 27-37.

Abedini A, Hassanabadi A, Afzali N, Kermanshahi H (2017). The effect of different dietary levels of Pennyroyal (Mentha Pulegium L.), probiotic and antibiotic on performance, carcass characteristics and, sellected nutrients digestibility in broiler chickens. Arch Med Lab Sci, 3 (2), 15-22.

Adibmoradi M, Navidshad B, Seifdavati J, Royan M (2006). Effect of dietary garlic meal on histological structure of small intestine in broiler chickens. J Poult Sci, 43 (4), 378-383.

Ahmed A, Ayoub K, Chaima AJ, Hanaa L, Abdelaziz C (2018). Effect of drying methods on yield, chemical composition and bioactivities of essential oil obtained from Moroccan Mentha pulegium L. Biocatal Agric Biotechnol, 16, 638-643.

Al-Jamal A-R and Alqadi T (2011). Effects of rosemary (Rosmarinus officinalis) on lipid profile of diabetic rats. Jordan J Biol Sci, 147 (622) 1-5.

Alagawany M, Ashour EA, Reda FM (2016). Effect of dietary supplementation of garlic (Allium sativum) and Turmeric (Curcuma longa) on growth performance, carcass traits, blood profile and oxidative status in growing rabbits. Ann Anim Sci, 16 (2), 489-505.

Basavaraj M, Nagabhushana V, Prakash N, et al. (2011). Effect of dietary supplementation of Curcuma longa on the biochemical profile and meat characteristics of broiler rabbits under summer stress. Vet World 4 (1), 15.

Bäuerl C, Collado MC, Zúñiga M, et al.(2014). Changes in cecal microbiota and mucosal gene expression revealed new aspects of epizootic rabbit enteropathy. PloS one, 9 (8), e105707.

Benlemlih M, Barchan A, Aarab A, Bakkali M, Arakrak A et al. (2020) Effect of Dietary Dried Fennel and Oregano and Thyme Supplementation on Zootechnical Parameters of Growing Rabbits. World, 10 (3), 332-337.

Botsoglou N, Florou-Paneri P, Christaki E, Giannenas I, Spais A (2004). Performance of rabbits and oxidative stability of muscle tissues as affected by dietary supplementation with oregano essential oil. Arch Anim Nutr, 58 (3), 209-218.

Cardinali R, Cullere M, Dal Bosco A, et al. (2015). Oregano, rosemary and vitamin E dietary supplementation in growing rabbits: Effect on growth performance, carcass traits, bone development and meat chemical composition. Livest Sci, 175, 83-89.

Cengiz S, Yesilbag D, Eren M, et al. (2016). Effects of volatile oil additives on growth, carcass performances, and calcium and phosphorus concentrations in serum and bone of broilers. Rev Med Vet (Toulouse), 167 (7-8), 230-239.

Cesari V, Toschi I, Pisoni A, Grilli G, Cesari N (2008). Effect of dietary acidification on growth performance and caecal characteristics in rabbits. Proc 9 th World Rabbit Congress.

Chen G, Wu J, Li C (2013). The effect of different selenium levels on production performance and biochemical parameters of broilers. Ital Anim Sci, 12 (4), e79.

El-Azeem A, Ahmed E, Al-Sagheer AA, Daader A, Bassiony S (2019). Effect of dietary supplementation with betaine, thyme oil and their mixtures on productive performance of growing rabbits. Zagazig $J$ Agric Res, 46 (3), 815-828.

El-Gogary M, El-Said E, Mansour A (2018). Physiological and immunological effects of rosemary essential oil in growing rabbit diets. JAgric Sci, 10, 485-491.
El-kaiaty AM, El-Moghazy GM, El-Manylawi MAF, Abdel-Mageed MGY (2020). Impact of thyme oil and lactobacillus acidophilus as natural growth promoters on performance, blood parameters and immune status in growing rabbits. J World's Poult Res, 10 (1), 1-11.

Elshafie HS and Camele I (2017). An overview of the biological effects of some mediterranean essential oils on human health. Biomed Res Int, 2017, ID9268468.

Elson C and Qureshi A (1995). Coupling the cholesterol-and tumorsuppressive actions of palm oil to the impact of its minor constituents on 3-hydroxy-3-methylglutaryl coenzyme A reductase activity. Prostaglandins Leukot Essent, 52 (2-3), 205-208.

Erdelyi M, Matics Z, Gerencsér Z et al. (2008). Study of the effect of rosemary (Rosmarinus officinalis) and garlic (Allium sativum) essential oils on the performance of rabbit. 9th World Rabbit Congress-June.

Gruenwald J, Brendler T, Jaenicke C (2000). Physician's desk reference (pdr) for herbal medicines. Medical Economics Company.

Halls AE (2010). Nutritional requirements for rabbits. Retrieved September, 21, 2014.

Ibrahim SA, El-Ghamry A, El-Mallah G (2000). Effect of some medicinal plants of Labiatae family as feed additives on growth and metabolic changes of rabbits. Egyptian J Rab Sci, 10 (1), 105-120.

Ishtiaq S, Ahmad M, Hanif U, Akbar S, Kamran SH (2014). Phytochemical and in vitro antioxidant evaluation of different fractions of Amaranthus graecizans subsp. silvestris (Vill.) Brenan. Asian Pac J Trop Med, 7, 342347.

Khaksar V, Van Krimpen M, Hashemipour H, Pilevar M (2012). Effects of thyme essential oil on performance, some blood parameters and ileal microflora of Japanese quail. J Poult Sci, 49 (2), 106-110.

Losa R and Kohler B (2001). Prevention of colonisation of Clostridium perfringens in broilers intestine by essential oils. Proc $13^{\text {th }}$ Eur Symp Poult Nutr, Blankenberge (Belgium).

Makav M and Ölmez M (2021). Effects of Pennyroyal (Mentha pulegium L.) on angiotensin converting enzyme-2 (ace-2) and antioxidant parameters in rabbits. J VetBio Sci Tech, 6 (1), 9-14.

Moore JE (2010). Natural standard herb and supplement guide: An evidence-based reference. Ulster Med J, 79 (3), 152-153.

Ölmez M, Adıgüzel Ișık S, Şahin T, Yörük M (2021). The effects of Pennyroyal (Mentha pulegium L.) on performance, carcass and meat quality in Japanese quails (Coturnix coturnix japonica). Ankara Üniv Vet Fak Derg, 68 (4), 2343-2348.

Ölmez M, Şahin T, Karadağoğlu ö, et al. (2020). The impact of an essential oil mixture on growth performance and intestinal histology in native Turkish geese (Anser anser). Kafkas Üniv Vet Fak Derg, 26 (5), 625-631.

Pebriansyah A, Lukešová D, Knížková I, Silberová P, Kunc P (2019). The effect of natural phytoadditive silybum marianum on performance of broiler rabbits. Sci Agric Bohem, 50 (1), 40-45.

Peiretti P, Masoero G, Meineri G (2011). Effects of replacing palm oil with maze oil and Curcuma longa supplementation on the performances, carcass characteristics, meat quality and fatty acid profile of the perirenal fat and muscle of growing rabbits. Anim, 5 (5), 795-801.

Placha I, Chrastinova L, Laukova A, et al. (2013). Effect of thyme oil on small intestine integrity and antioxidant status, phagocytic activity and gastrointestinal microbiota in rabbits. Acta Vet Hung, 61 (2), 197.

Reyan Mohasesi A, Darmani Koohi H, Naseri Harsini R, Mirza Aghazadeh A, Kioumarsi H (2020). Effect of Pennyroyal (Mentha Pulegium L.) on Performance, Carcass Characteristics and Some of the Blood Parameters in Broilers. J Environ Res Technol, 6 (6), 71.

Rotolo L, Gai F, Nicola S, et al. (2013). Dietary supplementation of oregano and sage dried leaves on performances and meat quality of rabbits. $J$ Integr Agric, 12 (11), 1937-1945.

Sakthi Priya M, Gopala Krishna Murthy T, Vijayanand T (2017). Effect of blend herbal supplement on haematology and serum biochemistry in commercial layer chicken. J World Poult Res, 7 (2), 48-56.

Sunarno S, Zubaedah S, Rini ANS, Sekarsari E, Rahadian R (2019) Cinnamon and gotu kola supplementation to produce high antioxidant and low cholesterol of quail pectoral meat. Biosaintifika J Biol Biol Educ, 11 (1), 148-155.

Şahin T, Karadağoğlu Ö, Sarı M (2012). Effects of Ground Echinacea (Echinacea purpurea)Supplementation Quail Diets on Growth Performance and Carcass Traits. Kafkas Univ Vet Fak Derg, 18 (1), 1519.

Sahin T, Sural T, Ölmez M, Karadağoğlu Ö (2020). Effects of herbal extract mixtures on performance, carcass yield and some internal organ weight in broilers. Vet Hek Der Derg, 91 (2), 137-146.

Tousson E, El-Moghazy M, El-Atrsh E (2011). The possible effect of diets containing Nigella sativa and Thymus vulgaris on blood parameters and some organs structure in rabbit. Toxicol Ind Health, 27 (2), 107116. 
Velpandian T, Jasuja R, Bhardwaj R, Jaiswal J, Gupta S (2001). Piperine in food: interference in the pharmacokinetics of phenytoin. Eur J Drug Metab Pharmacokinet, 26 (4), 241-247.

Wahyuni AETH, Prakasita VC, Nahak TEM, et al. (2019). Peluang imbuhan pakan herbal-probiotik komersial "promix®" sebagai pengganti antibiotic growth promoter (agp) pada ayam pedaging yang diberi vaksin ND. J Sain Vet, 37 (2), 180-184.

Zengin G, Aumeeruddy-Elalfi Z, Mollica A, Yilmaz MA, Mahomoodally MF (2018). In vitro and in silico perspectives on biological and phytochemical profile of three halophyte species-A source of innovative phytopharmaceuticals from nature. Phytomedicine, 38, 3544.

Zeweil H, Zahran S, Ahmed M, Morshedy S, El-Mabrok B (2017). Effects of essential oils supplementation on growth performance, digestibility coefficients and carcass characteristics of growing rabbits. J Adv Agric Res, 22 (4), 650-660. 